\title{
The Vertical Distribution of Marine Macroplankton. VIII. Further Observations on the Diurnal Behaviour of the Pelagic Young of Teleostean Fishes in the Plymouth Area.
}

\author{
By \\ F. S. Russell, D.S.C., B.A., \\ Assistant Naturalist at the Plymouth Laboratory.
}

With 6 Figures in the Text.

ON June 3rd-4th, 1926, a further series of observations was taken to study the diurnal behaviour of the post-larvæ of teleostean fishes. Collections were made in exactly the same way as on previous occasions (3) at a position about 2 miles east of the Eddystone Lighthouse. The net used was the 2-metre stramin ring-trawl, and the duration of each haul was ten minutes. The Admiralty depth-recording instrument was used and tracings of the path of the net through the water on each occasion are given in Fig. 1. The complete log giving details for each haul is set out in Table I ; all times are Greenwich mean ; and Table II gives the average depths for each haul obtained from the depth-recorder tracings.

\section{General Results.}

Larger catches of post-larval fish were taken than on the two previous dates when collections of this type were made, viz. July 15th to 16th, 1924, and June 17th to 19th, 1925. The results bear out the general conclusions arrived at for the previous collections.

The diurnal movements undertaken by most of the species of young fish would appear to be very slight. While a small proportion of each species tends to move into the upper layers near the surface at night, the greater part show little change from their usual daytime distribution and are still found in the deeper layers. 


\section{TABLE I.}

Date: June 3rd-4th, 1926. Position : 2 miles east of Eddystone. Ship : s.s. Salpa.

Gear : 2 metre ring-trawl.

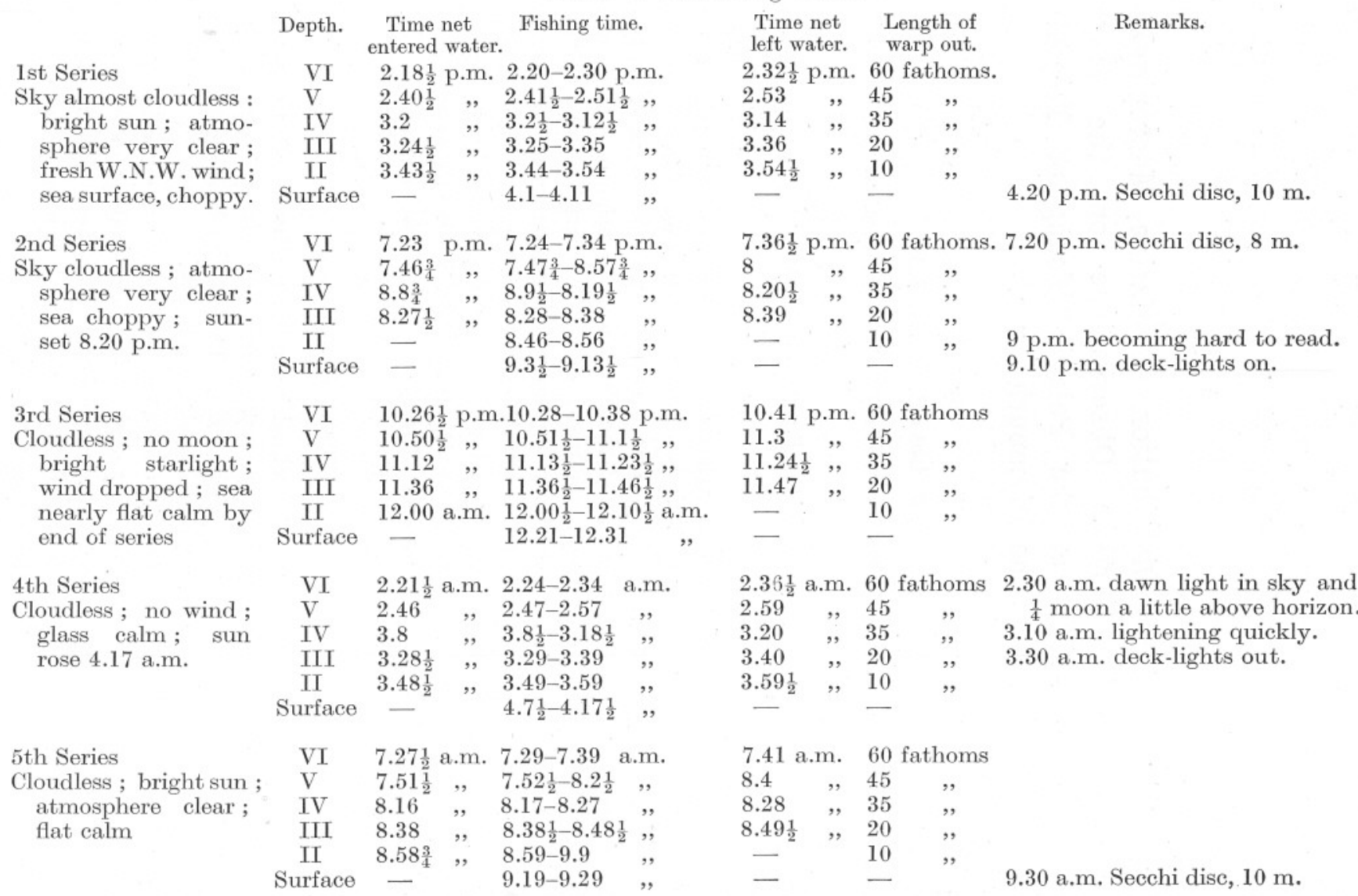

sea surface, choppy.

nd Series

sea choppy; sun-

end of series

Surface left wate

$2.53, \quad 45$

$3.14,, \quad 35$

$3.36 \quad, \quad 20$

$.36 \frac{1}{2}$ p.m. 60 fathoms. 7.20 p.m. Secchi dise, $8 \mathrm{~m}$.

$8 \quad, \quad 45$

$8.20 \frac{1}{2} \quad, \quad 35$

$8.39 \quad, \quad 20$

- 
METRES

METRES
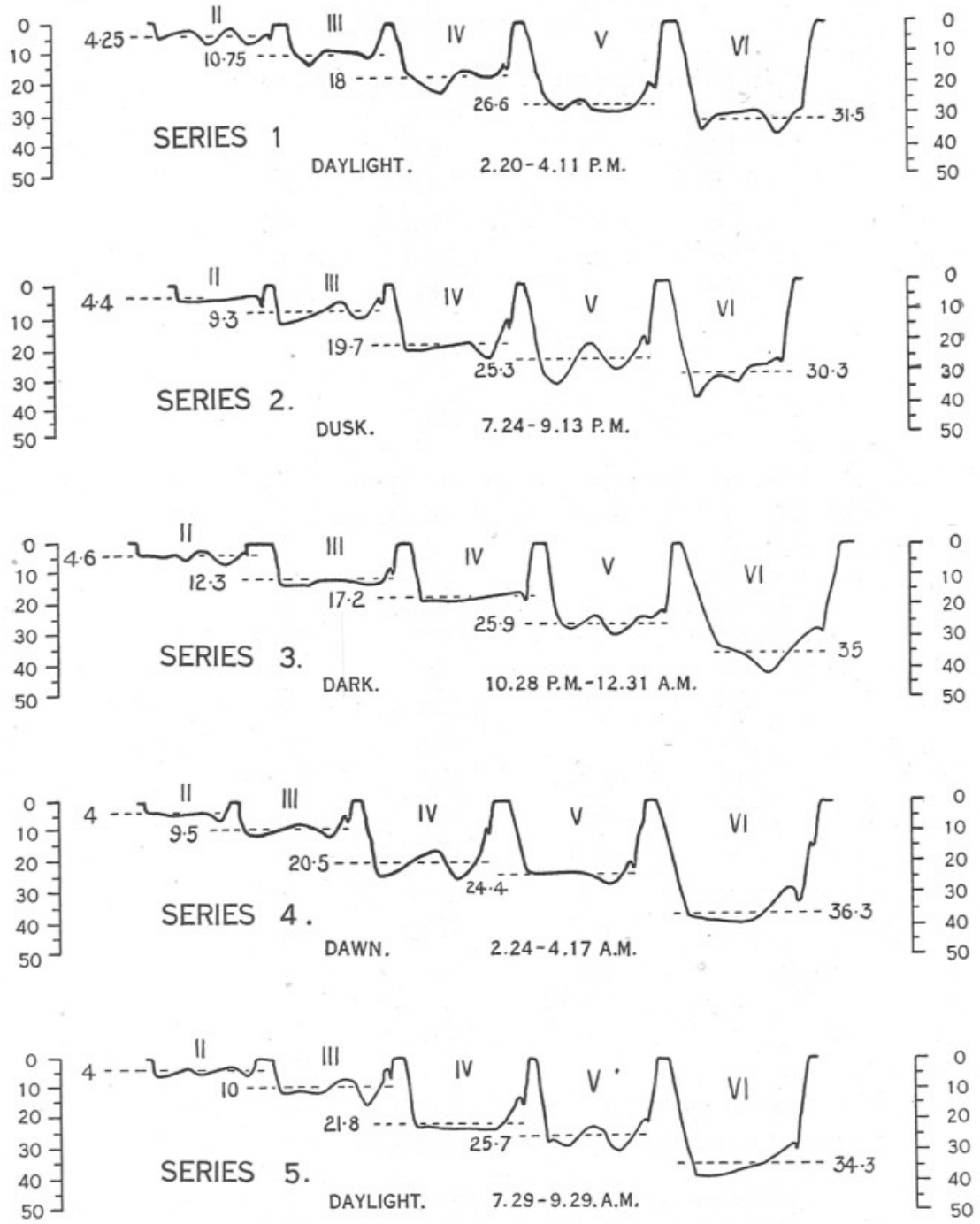

FIG. 1.-The five series of curves given by the depth-recorder indicating the path of the net through the water at five depths during the collections on June 3rd-4th, 1926. (The surface haul is not included.) The net enters the water on the right-hand side of each curve. The dotted lines indicate the calculated " average depths." 


\section{TABLE II.}

Average Depth in Metres for each Haul ON JUNE 3RD-4TH, 1926.

$\begin{array}{lccccc} & \text { 1st Series. } & \text { 2nd Series. } & \text { 3rd Series. } & 4 \text { th Series. } & \text { 5th Series } \\ \text { Surface } & - & - & - & - & - \\ \text { II } & 4 \cdot 25 & 4 \cdot 4 & 4 \cdot 6 & 4 & 4 \\ \text { III } & 10 \cdot 75 & 9 \cdot 3 & 12 \cdot 3 & 9 \cdot 5 & 10 \\ \text { IV } & 18 & 19 \cdot 7 & 17 \cdot 2 & 20 \cdot 5 & 21 \cdot 8 \\ \text { V } & 26 \cdot 6 & 25 \cdot 3 & 25 \cdot 9 & 24 \cdot 4 & 25 \cdot 7 \\ \text { VI } & 31 \cdot 5 & 30 \cdot 3 & 35 & 36 \cdot 3 & 34 \cdot 3\end{array}$

TABLE III.

Total Numbers of Post-larve caught in each Haul on June 3rd4TH, 1926, Exclusive of those of Clupea sp., Gobius sp., AND Callionymus sp.

\begin{tabular}{|c|c|c|c|c|c|}
\hline & $\begin{array}{l}\text { 1st Series. } \\
\text { Daylight. }\end{array}$ & $\begin{array}{c}\text { 2nd Series. } \\
\text { Dusk. }\end{array}$ & $\begin{array}{c}\text { 3rd Series. } \\
\text { Dark. }\end{array}$ & $\begin{array}{c}\text { 4th Series. } \\
\text { Dawn. }\end{array}$ & $\begin{array}{l}\text { 5th Series. } \\
\text { Daylight. }\end{array}$ \\
\hline Surface & 9 & 39 & 59 & 3 & 45 \\
\hline II & 14 & 94 & 123 & 39 & 98 \\
\hline III & 84 & 99 & 181 & 97 & 140 \\
\hline IV & 217 & 220 & 182 & 125 & 174 \\
\hline V & 235 & 128 & 252 & 92 & 177 \\
\hline VI & 161 & 200 & 182 & 62 & 74 \\
\hline Total & $\overline{720}$ & $\overline{780}$ & $\overline{979}$ & $\overline{418}$ & $\overline{708}$ \\
\hline
\end{tabular}

TABLE IV.

Total Numbers of different Species of Fish Post-larv \& occurring IN the Collections made on June 3RD-4TH. 1926.

$\begin{array}{lccccr} & \begin{array}{c}\text { 1st Series. } \\ \text { Daylight. }\end{array} & \begin{array}{c}\text { 2nd Series. } \\ \text { Dusk. }\end{array} & \begin{array}{c}\text { 3rd Series. } \\ \text { Dark. }\end{array} & \begin{array}{c}\text { 4th Series. } \\ \text { Dawn. }\end{array} & \begin{array}{r}\text { 5th S } \\ \text { Daylight }\end{array} \\ \text { Surface } & 6 & 5 & 15 & 5 & 8 \\ \text { II } & 11 & 13 & 20 & 16 & 19 \\ \text { III } & 17 & 18 & 19 & 22 & 15 \\ \text { IV } & 19 & 20 & 17 & 21 & 16 \\ \text { V } & 21 & 20 & 21 & 24 & 18 \\ \text { VI } & 22 & 21 & 20 & 21 & 19\end{array}$


The Clupeids, however, form a notable exception to this rule, showing a very marked increase in numbers at night. On this occasion they consisted of a mixture of Sprats and Pilchards, and they repeated almost exactly the behaviour shown by the young pilchards in the previous years (3). The only other species that showed a similar increase at night were the Gobies.

Table III shows the number of post-larvæ taken at each depth of all species, exclusive of those of the Clupeids and the Gobies and also of Callionymus sp., which occurred in such numbers as to outweigh all other fish. This table shows very clearly that while there was a general increase in numbers at the surface and in the upper layers down to about 10 metres at night, there was little change in the deeper hauls from that of the daytime. It shows also that in daylight on June 4th (Series 5) there were again nearly as many fish in the surface layers as at night; this was, no doubt, due to the presence of immense swarms of Calanus which must have decreased the light intensity to a considerable degree.

Table IV gives the total number of different species taken at each depth, and it can be seen that while the majority live in the deeper layers in the daytime, nearly all the species have been involved in the slight upward extension at night. In this respect also the results obtained in the previous years are substantially confirmed.

The general inference to be drawn from these few observations is that except in the case of Clupeids, Gobies, and possibly Callionymus (3, p. 408), it is probably safe to base conclusions of seasonal or horizontal distribution, of those species which have been here caught in significant numbers, from collections made either by day or by night with oblique hauls. This applies only to those species whose normal daytime distribution is well above the bottom, so that the complete range of their vertical distribution would be covered by an oblique haul. There is no evidence that the numbers taken at night would be so very much larger than day catches as to show differences greater than those occasioned by local unevenness in horizontal distribution. It must be admitted, however, that these conclusions are based on observations for four nights only, and more observations are certainly desirable, especially in May.

It is interesting to notice that very many of those species, that normally live in the deeper layers in the daytime, when caught near the surface at dawn and daylight on June 4th were very much mutilated. This has been noticed on previous occasions and suggests that during the great mixing up of plankton organisms at night extensive feeding is taking place and dead or dying postlarval fishes are left behind in the upper layers when those that have escaped have retired to greater depths.

In the following pages each species is dealt with in detail. The actual 
numbers of all species caught are given in Table $X$, page 850, at the end of the paper. Throughout the expressions "Daylight," "Dusk," "Dark," and "Dawn" have been used to cover the various periods at which collections were made ; the actual times, however, are given in the various figures and tables.

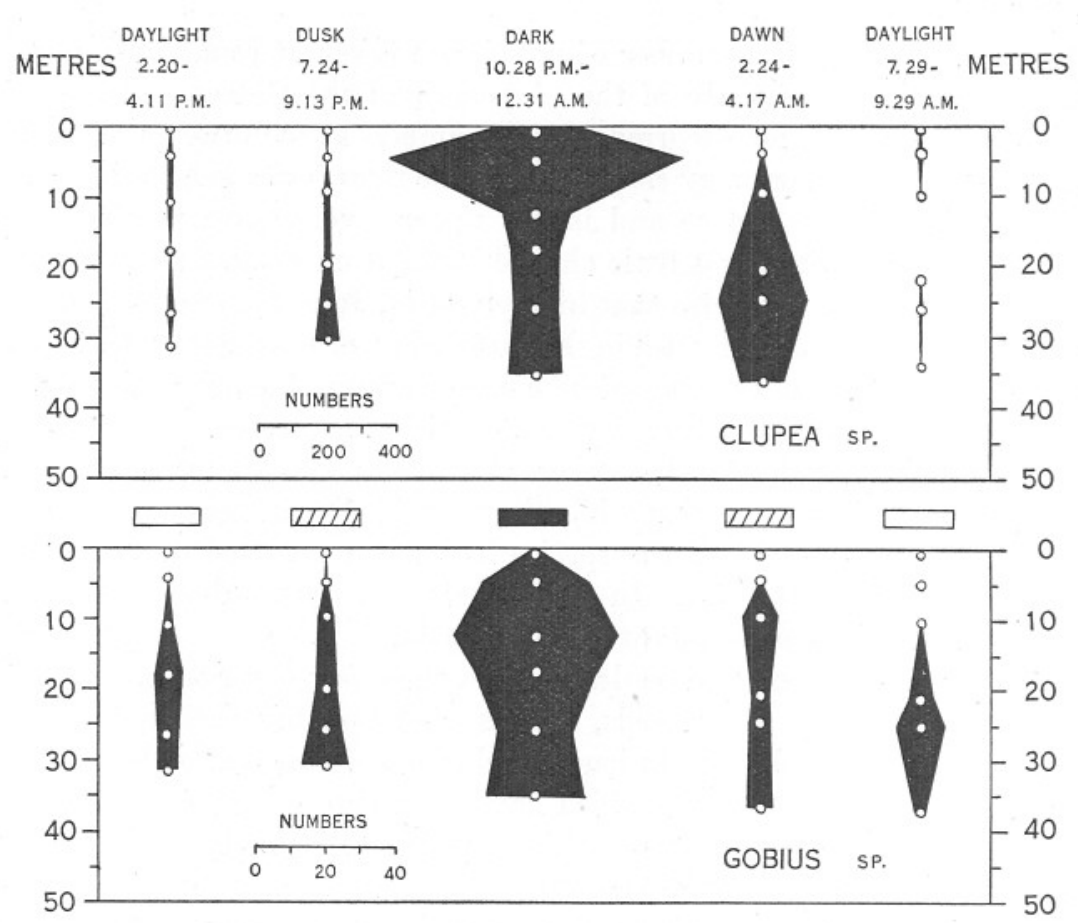

Frg. 2.-The vertical distribution of Clupea sp. (C. sprattus and S. pilchardus) and Gobius sp. post-larvæ, at the times shown, on June 3rd-4th, 1926. The white spots and black circles indicate the "average depths" at which hauls were taken. The plain, cross-hatched, black, and shaded rectangles represent " daylight," " dusk," " dark," and "dawn" respectively.

\section{CLUPEID Æ.}

\section{Clupea sprattus L. and Sardina pilchardus (Walb.).}

The Clupeid post-larvæ consisted of a mixture of Clupea sprattus and Sardina pilchardus, all under $24 \mathrm{~mm}$. in length and mostly between 10 and $20 \mathrm{~mm}$. Fig. 2, which gives the vertical distribution of these postlarvæ together, shows that hardly any Clupeids were caught in the daytime on June 3rd at the depths sampled down to 31 metres, 15 individuals being the largest catch at any one depth. At dusk there was a slight increase in the layers below 20 metres, 41 and 77 being caught at $25 \cdot 3$ and $30 \cdot 3$ metres respectively. In the dark, however, there had been a very 
marked increase in numbers at all depths, the greatest catch of 852 specimens being taken at $4 \cdot 6$ metres. At dawn they had left the surface layers, but large numbers were still caught from 20 metres downwards. At daylight the next day the previous daytime distribution was repeated, the largest catch being only 13 .

In this behaviour the Sprat and Pilchard have exactly repeated that shown by the pilchard on the three previous nights examined in 1924 and 1925 (3, p. 396). On the present occasion, however, definite evidence seems to be afforded that the increase in numbers at night is due to the postlarvæ having moved up from the levels below 35 metres. The dawn distribution appears quite definitely to indicate a downward migration, and also at dusk the beginning of an upward migration is apparent in the deepest hauls.

The results of these four nights are of great importance and appear to show definitely that in June and July any study of the distribution of these post-larvæ must be carried out at night. On the three nights in 1924 and 1925 there were over ten times as many caught in the dark (or at dawn in 1924) as in the daytime, while in 1926 there were over thirty times as many caught at night.

Quite the same results were obtained by Johansen (2, p. 12) in Danish waters for the young herring, Clupea harengus L., many more both of the winter-spawned and of the autumn-spawned herring being caught at night than in the daytime in April, 1925.

\section{GADID $Æ$.}

\section{Gadus merlangus L.}

A study of Table X, page 850, shows that while in the daylight on both days the majority of whiting post-larvæ occurred below 10 metres, at dusk there were very large catches at the surface and in the layers above 10 metres. In the dark there were very few caught, and the majority of these were again below 10 metres, while at dawn the numbers were rather too low to be significant.

Before, however, we can draw conclusions as to the behaviour of these young whiting, it is necessary to analyse the catches and see what sizes the post-larvæ are. In Table $V$ are given the sizes and total numbers of specimens taken in each haul. It is at once evident that the great increase in numbers in the surface layers at dusk is caused by the presence of specimens of $12 \mathrm{~mm}$. and longer, which were completely absent in the daytime on June 3rd. The very large catches in the daylight on June 4th are also due to post-larvæ of $12 \mathrm{~mm}$. and over. Examination of the plankton samples shows that there is obviously a correlation between the abundance of these larger stages and the presence or absence of Cyanea capillata. 
Table V.

Gadus merlangus,

Length in Millimetres.

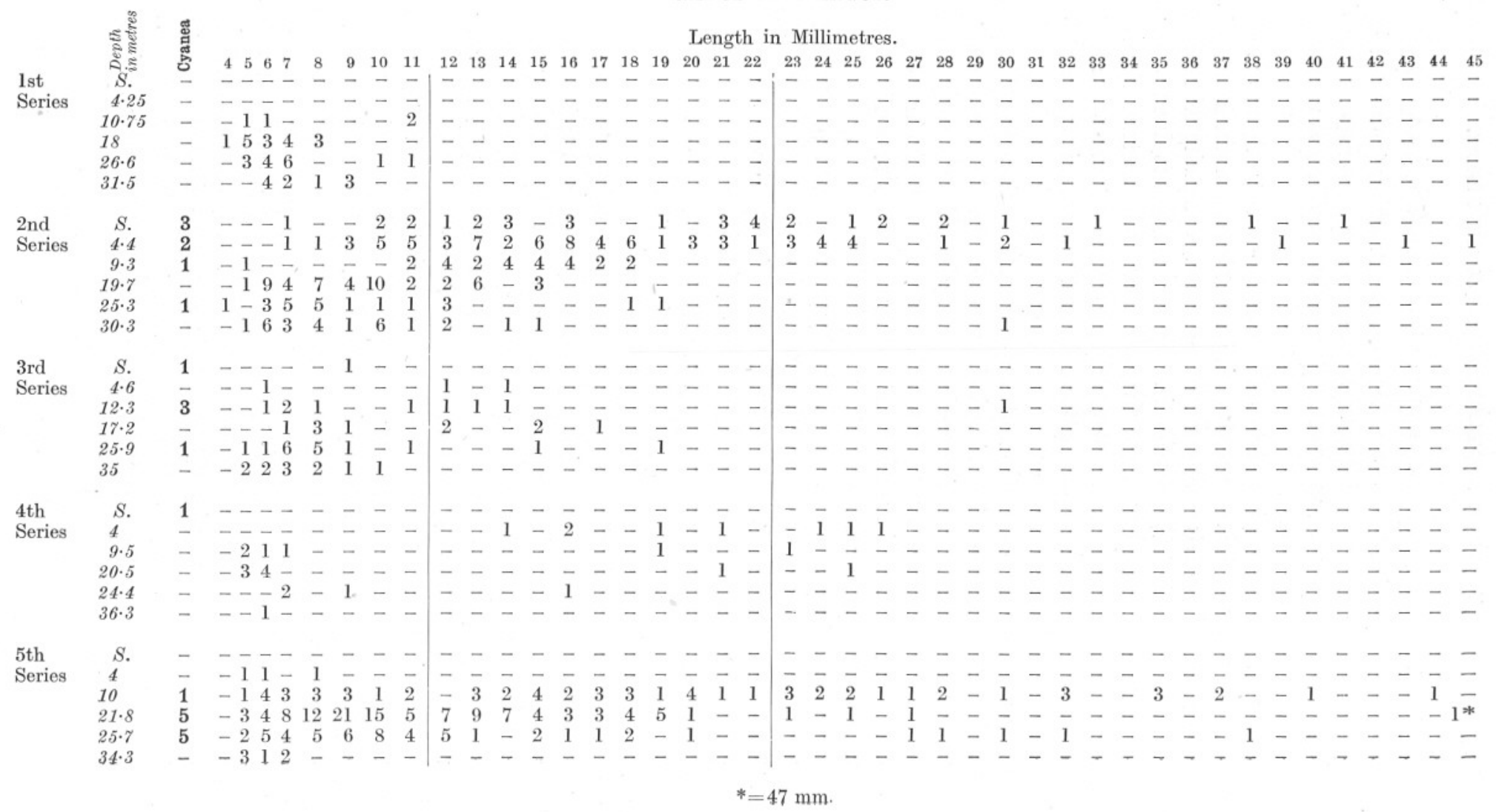




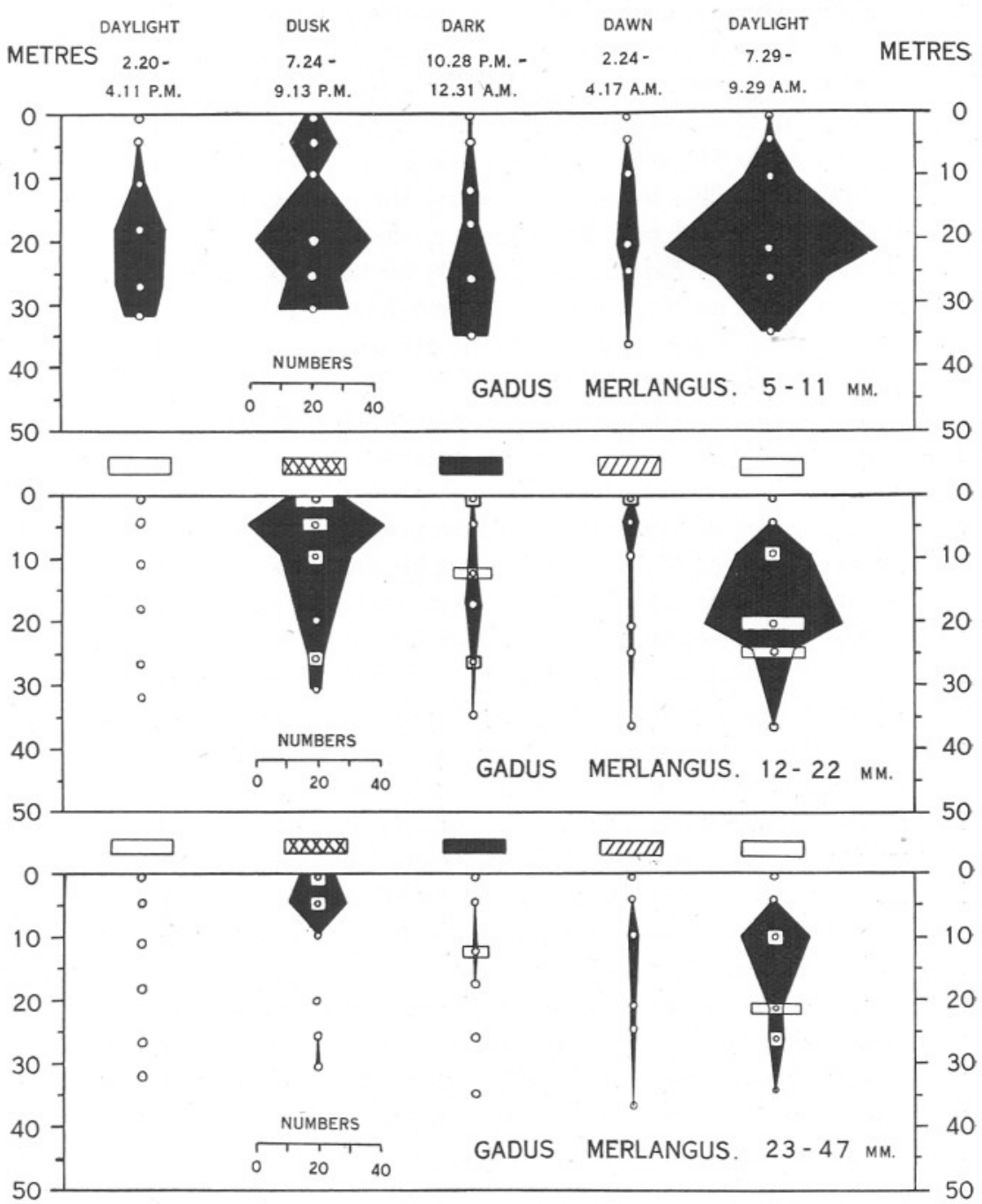

FIG. 3.-The vertical distribution of Gadus merlangus of different sizes, viz. 5-11 mm. 12-22 mm., and 23-47 mm., at the times shown, on June 3rd-4th, 1926. The presence of Cyanea is also indicated in the lower two diagrams as white oblong blocks at the depths at which they occurred (for numbers see Table VI). (In haul V of the 5 th series the oblong is too small and should be the same size as that immediately above it, corresponding to 3 Cyanea.) The white spots and black circles indicate the "average depths " at which hauls were taken. The plain, cross-hatched, black, and shaded rectangles represent "daylight," "dusk," "dark," and "dawn" respectively. 
Damas (1, p. 42) was of the opinion that the association of the young whiting with Cyanea begins after the fish has almost completely metamorphosed at a length of $23 \mathrm{~mm}$. It would seem from Tables V and VI, however, that in these waters the association may begin considerably earlier, since in the daytime specimens of $12 \mathrm{~mm}$. and over only occurred in the catches when Cyanea was also present. In Table VII I have accordingly given the catches in each haul of the three size groups, 4 to $11 \mathrm{~mm}$, 12 to $22 \mathrm{~mm}$., and $23 \mathrm{~mm}$. upwards, i.e. the size quoted by Damas. I have also indicated by single asterisks (*) for the two smaller size groups the hauls in which any Cyanea at all occurred, and by double asterisks (**) in the case of the largest size group the occurrence of large Cyanea, four or more inches in diameter.

This table shows that post-larvæ of the whiting from 4 to $11 \mathrm{~mm}$. in length occurred irrespective of whether there were Cyanea present in the catches. The occurrence of specimens between 12 and $22 \mathrm{~mm}$. however showed quite a close correlation with the presence or absence of Cyanea ; while whiting of over $23 \mathrm{~mm}$. were practically associated only with Cyanea of quite a large size, namely, four or more inches in diameter. In Fig. 3 these same data are shown graphically, and it can be seen very clearly that in the case of specimens less than $12 \mathrm{~mm}$. in length there was little indication of any vertical movement throughout the 24 hours. As regards the two larger size groups there was obviously a migration to the surface at dusk, but this was a movement also undertaken by Cyanea, and the indications are very strong that the whiting have merely followed the Cyanea towards the surface. This behaviour has already been noticed by Damas (1, p. 43), who says: "Pendant la longue période où le jeune merlan vit en commensal des méduses, sa distribution bathymétrique est aisée à déterminer. On peut l'observer pendant des journées entières à un niveau plus ou moins élevé et variable avec l'heure du jour. Il suit les méduses dans leur migrations verticales. Celles-ci sont particulièrement marquées par les jours de ciel clair et paraissent dirigées par un phototropisme accentué. Pendant les heures du jour, les méduses et leurs hôtes sont absent de la surface, on a peine à les découvrir à une dizaine de mètres de profondeur. Elles remontent au crépuscule. Après une journée de calme parfait, durant laquelle il n'a été possible de découvrir aucun signe de vie à la surface, on peut assister à la tombée de la nuit à un spectacle qui donne une idée de l'abondance des méduses et en consequence du jeune merlan. Aussi loin que l'œil peut porter, la mer semble frappée par une pluie abondante et silencieuse. Cet effet est dû aux méduses choquant la surface à chaque contraction du disque." 
TABLE VI.

Numbers and Sizes (Diameter in inches) of Cyanea capillata occurring in thr Ring-trawl Catches on June 3RD-4th, 1926.

\begin{tabular}{|c|c|c|c|c|c|}
\hline & $\begin{array}{l}\text { 1st Series. } \\
\text { Daylight. }\end{array}$ & $\begin{array}{c}\text { 2nd Series. } \\
\text { Dusk. }\end{array}$ & $\begin{array}{l}\text { rd Series. } \\
\text { Dark. }\end{array}$ & $\begin{array}{l}\text { 4th Series. } \\
\text { Dawn. }\end{array}$ & $\begin{array}{l}\text { 5th Series. } \\
\text { Daylight. }\end{array}$ \\
\hline Surface & - & $3\left(5^{\prime \prime} ; 2^{\prime \prime} ; 2^{\prime \prime}\right)$ & ") $1\left(2 \frac{1}{2}^{\prime \prime}\right)$ & $1\left(\frac{3{ }^{\prime \prime}}{4}\right)$ & - \\
\hline II & - & $2\left(4^{\prime \prime} ; 3^{\prime \prime}\right)$ & - & - & - \\
\hline III & - & $1\left(3^{\prime \prime}\right)$ & $3\left(2^{\prime \prime} ; 4 \frac{1}{2}\right.$ & $\left." 6^{\prime \prime}\right)-$ & $1\left(4^{\prime \prime}\right)$ \\
\hline IV & - & - & - & - & \\
\hline $\mathrm{V}$ & - & $1\left(3^{\prime \prime}\right)$ & $1\left(1 \frac{3{ }^{\prime \prime}}{4}\right)$ & - & \\
\hline VI & - & - & - & - & - \\
\hline
\end{tabular}

TABLE VII.

Distribution of Different Size Groups of Whiting and occurrence of Cyanea.

\begin{tabular}{|c|c|c|c|c|c|}
\hline & $\begin{array}{l}\text { Ist Series. } \\
\text { Daylight. }\end{array}$ & $\begin{array}{l}\text { 2nd Series } \\
\text { Dusk. }\end{array}$ & $\begin{array}{l}\text { 3rd Series. } \\
\text { Dark. } \\
\text { mm. }\end{array}$ & $\begin{array}{l}\text { 4th Series. } \\
\text { Dawn. }\end{array}$ & $\begin{array}{l}\text { 5th Series } \\
\text { Daylight }\end{array}$ \\
\hline S. & - & $5^{*}$ & $1^{*}$ & _* & - \\
\hline II & - & $15^{*}$ & 1 & - & 3 \\
\hline III & 4 & $3^{*}$ & $5^{*}$ & 4 & $17^{*}$ \\
\hline IV & 16 & 37 & 5 & 7 & $68^{*}$ \\
\hline $\mathrm{V}$ & 15 & $17 *$ & $15^{*}$ & 3 & $34 *$ \\
\hline VI & 10 & 22 & 11 & 1 & 6 \\
\hline \multicolumn{6}{|c|}{$12-22 \mathrm{~mm}$. } \\
\hline S. & - & $17 *$ & -* & _* & - \\
\hline II & - & $44^{*}$ & 2 & 5 & - \\
\hline III & - & $22 *$ & $3^{*}$ & 1 & $24 *$ \\
\hline IV & - & 11 & 5 & 1 & $43 *$ \\
\hline V & - & $5^{*}$ & $2 *$ & 1 & $13^{*}$ \\
\hline VI & - & 4 & - & - & - \\
\hline \multicolumn{6}{|c|}{$23-47 \mathrm{~mm}$. } \\
\hline S. & - & $11^{* * *}$ & - & - & - \\
\hline II & - & $18^{* * *}$ & - & 3 & - \\
\hline III & - & - & $1 * *$ & 1 & $22^{* * *}$ \\
\hline IV & - & - & - & 1 & $4^{* * *}$ \\
\hline $\mathrm{V}$ & - & - & - & - & $5^{* *}$ \\
\hline VI & - & 1 & - & - & - \\
\hline
\end{tabular}

* Presence of Cyanea.

** Presence of Cyanea 4 or more inches in diameter. 
Fig. 3 shows also that there is a slight indication that at night the young whiting may separate from the Cyanea, because although Cyanea were present in some of the catches, the numbers of whiting of $12 \mathrm{~mm}$. or more were very few; also at dawn a few whiting were caught but no Cyanea. This, however, is only a bare indication.

\section{Gadus minutus (0. F. Müll.).}

As usual the post-larvæ of this species were scarcely taken at all above a depth of 25 metres in the daytime. At dusk and in the dark there was hardly any change in their vertical distribution, except that in the dark a few were taken in the layers above 20 metres up to 5 metres below the surface (Fig. 4). At dawn the numbers were rather too low to be at all

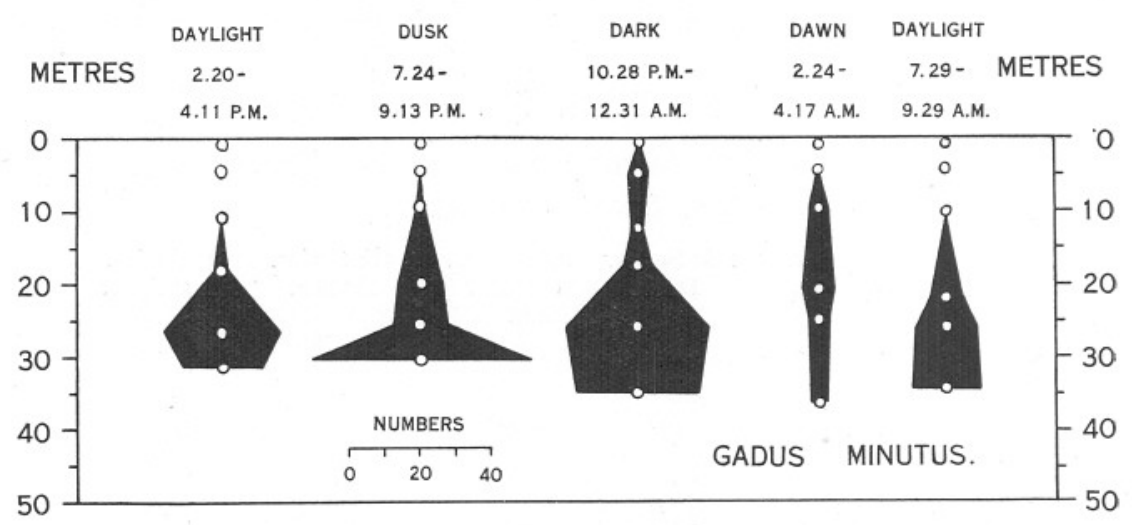

FrG. 4.-The vertical distribution of Gadus minutus, at the times shown, on June 3rd-4th, 1926. The white spots and black circles indicate the "average depths" at which hauls were taken.

significant. An examination of the sizes of these post-larvæ showed that in the daytime they were all between 4 and $11 \mathrm{~mm}$. in length. At dusk and in the dark, however, a few appeared in the deeper layers 12 to $15 \mathrm{~mm}$. in length, and one $20 \mathrm{~mm}$. long was caught at 20.5 metres at dawn.

\section{ONOS SP.}

Post-larval rockling were not very abundant in daylight on June 3rd or at dusk, the few there were being evenly distributed from the surface downwards. At night more were caught, the largest catch of 21 specimens being from the surface itself. Again, very few were taken at dawn, but in the daylight on June 4th another large catch of 28 was taken at the surface itself.

Of the remaining Gadoids, Gadus pollachius L., Gadus luscus L., Molva molva L., and Merluccius merluccius L., very few were taken. Of these 
G. pollachius and $M$. merluccius post-larvæ only occurred singly, while $G$. luscus and $M$. molva were only caught in the deeper levels.

\section{BOTHIDA.}

\section{Scophthalmus norvegicus (Günther).}

Large numbers of the post-larvæ of this species were captured in each series of hauls. In daylight on June 3rd the majority occurred at depths between about 14 metres and 31.5 metres, the deepest depth sampled (Fig. 5). At dusk there had been a slight upward movement, the greatest catch occurring at $19 \cdot 7$ metres. In the dark there was evidence of an increase in number at all depths and an extension upwards of a few to the surface itself, although the majority still lay below about 10 metres. An examination of Table VIII, which gives the sizes of the post-larvæ caught at each depth, shows that this increase in numbers is due to an influx of individuals of $8 \mathrm{~mm}$. or over. While the total number of specimens from 4-7 $\mathrm{mm}$. inclusive was in the daytime 142 and in the dark 143, those of 8-11 mm. increased in number from 18 in the daylight to 60 in the dark.

At dawn, although there were fewer taken at all depths, the majority occurred between 5 and 25 metres. In the daylight on June 4 th there was, however, a marked rise towards the surface, the greatest catch being at 4 metres. It is probable that this rise towards the suriace was occasioned by a diminution of light intensity caused by an extremely dense swarm of Calanus finmarchicus. Examination of my records (not yet published) showed that Calanus also exhibited this upward movement, and that their numbers were so great that they may well, so to speak, have caused their own shading.

An interesting corroboration of the fact that there appears to be some factor (probably light intensity) which governs all species alike occurs here. Research has shown that there are associations of animals which live at the same depths, and in the upper layers amongst such species as Calanus, Upogebia larvæ, and Turris appear also the post-larval stages of Scophthalmus norvegicus, Callionymus sp., and Trigla sp. Fig. 6, page 846 , shows that Callionymus sp. exhibited almost the same rise to the surface in the daylight on June 4th as did S. norvegicus. This suggests that possibly these young fish may be limited in their upward movements by their speed of swimming. At dusk the light wanes so quickly that they have no time to reach the surface by following their optimum intensity, and in the dark owing to the absence of the light stimulus there is no incentive to move towards the surface and the young fish move about anywhere, most staying at the levels at which they already were. It is very different, however, if the intensity is lowered during the daytime 
by the persistent presence of a swarm of Calanus. Under such conditions the light is not changing rapidly, but remains constantly low. The fish then have time to pick up their optimum level.

In comparison with the records for previous years $S$. norvegicus has always behaved in the same manner.

\section{TABLE VIII.}

\begin{tabular}{|c|c|c|c|c|c|c|c|c|c|c|}
\hline & & & HTH & LMU & NOI & EGIC & & & & \\
\hline & Depth in & & & & th in & iillim & & & & $\begin{array}{l}\text { Total } \\
\text { numbers }\end{array}$ \\
\hline & metres. & 4 & 5 & 6 & 7 & 8 & 9 & 10 & 11 & of fish. \\
\hline 1st Series & $S$. & - & - & - & - & - & - & - & - & 0 \\
\hline & $4 \cdot 25$ & - & - & 1 & 1 & - & - & - & - & 2 \\
\hline & 10.75 & - & 4 & 5 & 5 & - & - & - & - & 14 \\
\hline & 18 & 3 & 12 & 13 & 10 & 4 & 1 & - & - & 43 \\
\hline & $26 \cdot 6$ & 2 & 16 & 16 & 19 & 6 & - & 1 & - & 60 \\
\hline & $31 \cdot 5$ & 6 & 13 & 12 & 5 & 6 & 1 & - & - & 43 \\
\hline 2nd Series & $S$. & - & - & - & 1 & - & - & - & - & 1 \\
\hline & $4 \cdot 4$ & - & - & 3 & - & - & - & - & - & 3 \\
\hline & $9 \cdot 3$ & - & 5 & 9 & 4 & 4 & - & - & - & 22 \\
\hline & $19 \cdot 7$ & 2 & 4 & 9 & 8 & 14 & 5 & 2 & - & 44 \\
\hline & $25 \cdot 3$ & 1 & 4 & 10 & 8 & - & - & - & - & 23 \\
\hline & $30 \cdot 3$ & 1 & 1 & 5 & 9 & 2 & - & 1 & - & 19 \\
\hline 3rd Series & $S$. & - & - & 2 & 4 & - & 1 & - & _- & 7 \\
\hline & $4 \cdot 6$ & 1 & 5 & 4 & 3 & 4 & - & - & - & 17 \\
\hline & $12 \cdot 3$ & 1 & 9 & 11 & 11 & 7 & 4 & 2 & - & 45 \\
\hline & $17 \cdot 2$ & - & 3 & 14 & 15 & 18 & 2 & - & 1 & 53 \\
\hline & 25.9 & 2 & 11 & 10 & 17 & 7 & 3 & 3 & - & 53 \\
\hline & 35 & 1 & 6 & 4 & 9 & 7 & - & 1 & - & 28 \\
\hline 4th Series & $S$. & - & 1 & - & - & - & - & - & - & 1 \\
\hline & 4 & - & 2 & 3 & - & - & - & - & - & 5 \\
\hline & $9 \cdot 5$ & 3 & 10 & 6 & 1 & - & - & - & - & 20 \\
\hline & $20 \cdot 5$ & 1 & 8 & 5 & 10 & - & 1 & - & - & 25 \\
\hline & $24 \cdot 4$ & - & 1 & 5 & 2 & 4 & - & - & - & 12 \\
\hline & $36 \cdot 3$ & - & - & 1 & - & - & 1 & 2 & - & 4 \\
\hline 5th Series & $S$. & - & 3 & 4 & 1 & - & - & - & - & 8 \\
\hline & 4 & 3 & 14 & 17 & 7 & 3 & 1 & - & - & 45 \\
\hline & 10 & - & 3 & 9 & 9 & 7 & 4 & - & - & 32 \\
\hline & 21.8 & 1 & 2 & 8 & 2 & 4 & - & - & - & 17 \\
\hline & $25 \cdot 7$ & 2 & 8 & 9 & 6 & 5 & 2 & - & - & 32 \\
\hline & $34 \cdot 3$ & - & 1 & 3 & 2 & 1 & - & - & - & 7 \\
\hline
\end{tabular}

\section{Zeugopterus punctatus (Bloch.).}

Only a few post-larvæ of this species were taken, and it can be seen from Table X, page 850, that the majority were always below a depth of 10 metres.

Post-larvæ of Arnoglossus sp., 5-9 mm. in length, only occurred in a few hauls and then nearly always singly. 


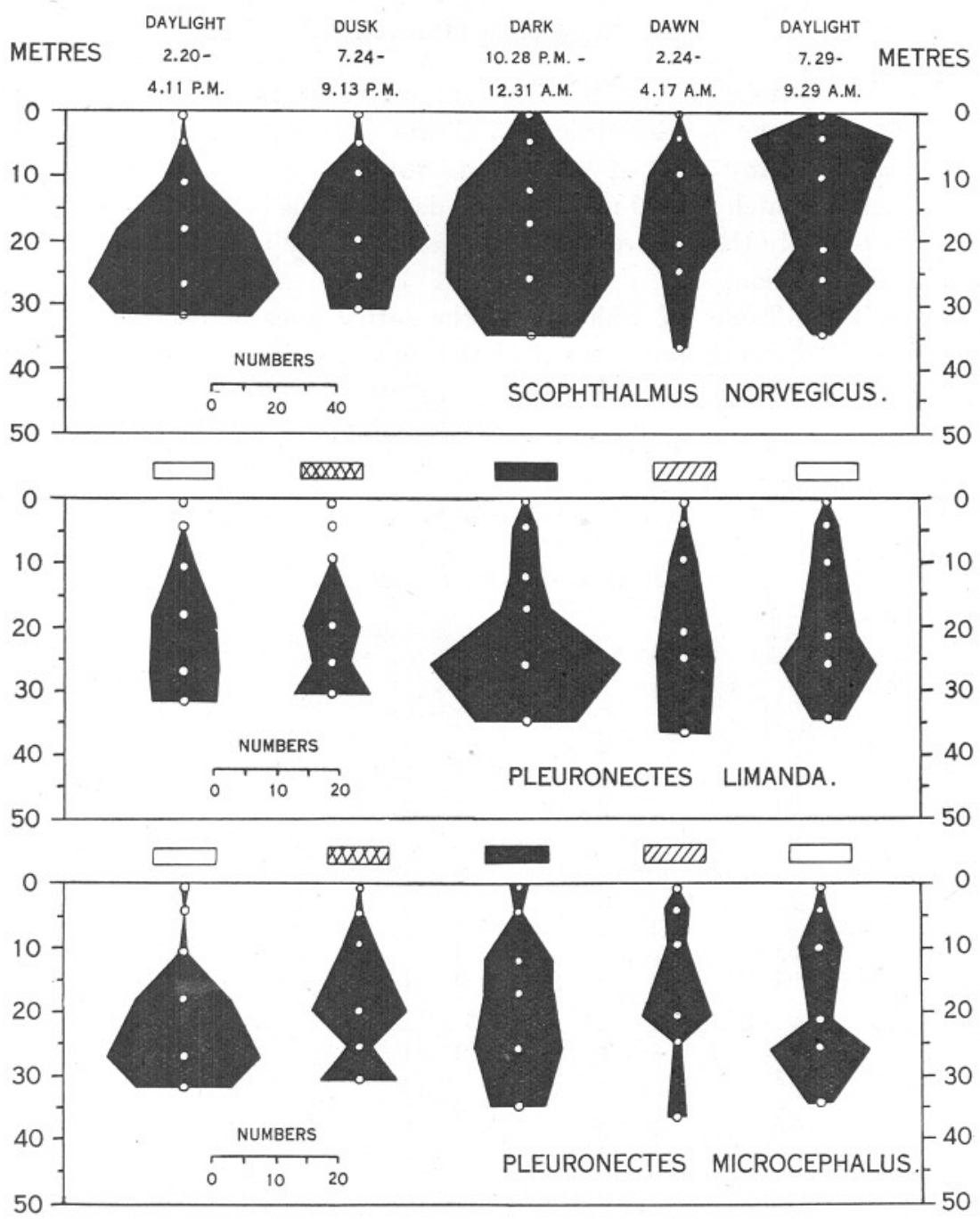

FIG. 5.-The vertical distribution of Scophthalmus norvegicus, Pleuronectes limanda, and P. microcephalus, at the times shown, on June 3rd-4th, 1926. The white spots and black circles indicate the "average depths " at which hauls were taken. The plain, cross-hatched, black, and shaded rectangles represent " daylight," "dusk," "dark," and "dawn" respectively. 


\section{PLEURONECTID $A$.}

\section{Pleuronectes limanda $\mathrm{L}$.}

Post-larval stages of the dab were not very abundant. The majority were taken in the daytime below 15 metres (Fig. 5), and there were no indications of any marked movements towards the surface at night. Although the catch at 25.9 metres in the dark was the largest at any time, it is quite likely that this was merely occasioned by unevenness in horizontal distribution.

A study of Table IX which gives the actual sizes of the post-larvæ caught at each depth shows, however, that in the dark there was evidently quite a definite incursion of early bottom stages from 13 to $17 \mathrm{~mm}$. in length.

Table IX.

\section{Pleuronectes limanda.}

\begin{tabular}{|c|c|c|c|c|c|c|c|c|c|c|c|c|c|c|c|}
\hline \multirow{8}{*}{ 1st Series } & 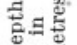 & \multicolumn{13}{|c|}{ Length in millimetres. } & sis \\
\hline & & 5 & 6 & 7 & 8 & 9 & 10 & 11 & 12 & 13 & 14 & 15 & 16 & 17 & $\stackrel{2}{*}$ \\
\hline & $S$. & - & - & - & - & - & - & - & - & - & - & - & - & - & \\
\hline & $4 \cdot 25$ & - & - & - & - & - & - & - & - & - & - & - & - & - & \\
\hline & $10 \cdot 75$ & - & - & - & 2 & 1 & 1 & - & - & - & - & - & - & - & \\
\hline & 18 & - & - & 2 & 1 & 2 & 2 & 3 & - & - & - & - & - & - & 10 \\
\hline & $26 \cdot 6$ & - & 1 & 3 & 3 & 1 & 2 & - & 1 & $\overline{-}$ & - & - & - & - & 11 \\
\hline & 31.5 & - & - & 2 & 2 & - & 2 & 2 & - & 2 & - & - & - & - & 10 \\
\hline
\end{tabular}

\begin{tabular}{rccccccccccccccc} 
2nd Series & $S$. & - & - & - & - & - & - & - & - & - & - & - & - & - & - \\
& $4 \cdot 4$ & - & - & - & - & - & - & - & - & - & - & - & - & - & - \\
& $9 \cdot 3$ & - & - & - & - & - & - & - & - & - & - & - & - & - & - \\
& $19 \cdot 7$ & - & 1 & 1 & - & 1 & 3 & 2 & - & - & 1 & - & - & - & 9 \\
& $25 \cdot 3$ & - & - & 2 & - & 1 & 3 & - & - & - & - & - & - & - & 6 \\
\multirow{5}{*}{$3 r d$ Series } & $30 \cdot 3$ & - & 2 & - & 2 & 4 & 1 & 1 & 1 & - & 1 & - & - & - & 12 \\
& $S$. & - & - & - & - & - & - & - & - & - & - & - & - & - & - \\
& $4 \cdot 6$ & - & - & 1 & - & - & 1 & 1 & - & 1 & - & - & - & - & 4 \\
& $12 \cdot 3$ & - & - & - & 2 & - & - & - & - & 1 & - & 1 & 1 & - & 5 \\
& $17 \cdot 2$ & - & - & - & 2 & 3 & 1 & - & - & 1 & - & - & - & 1 & 8 \\
& $25 \cdot 9$ & - & 3 & 5 & 3 & 5 & 7 & 2 & - & 2 & - & 2 & - & 1 & 30 \\
& 35 & - & 3 & 5 & - & 4 & 1 & 1 & 1 & - & 1 & - & - & - & 16
\end{tabular}

4th Series

$$
\begin{array}{ccccccccccccccc}
S . & - & - & - & - & - & - & - & - & - & - & - & - & - & - \\
4 & - & - & - & 1 & - & - & - & - & - & - & - & - & - & 1 \\
9 \cdot 5 & - & - & 1 & 1 & 2 & - & - & - & - & - & - & - & - & 4 \\
20 \cdot 5 & - & - & 4 & 2 & 2 & - & - & - & - & - & - & - & - & 8 \\
24 \cdot 4 & - & - & 3 & 1 & 2 & 1 & 1 & - & - & 1 & - & - & - & 9 \\
36 \cdot 3 & - & - & 1 & - & 1 & 3 & 1 & - & - & - & 1 & 1 & - & 8
\end{array}
$$

5th Series

$\begin{array}{lllllllllllllll}S . & - & - & - & - & - & - & - & - & - & - & - & - & - & - \\ 4 & - & - & 1 & 3 & - & - & - & - & - & - & - & - & - & 4 \\ 10 & 1 & - & 3 & - & - & 1 & - & - & - & - & - & - & - & 5 \\ 21 \cdot 8 & - & - & 3 & 2 & 2 & 1 & - & 1 & - & - & - & - & - & 9 \\ 25 \cdot 7 & - & 5 & 3 & 2 & - & 2 & 1 & 1 & - & 1 & - & - & - & 15 \\ 34 \cdot 3 & - & - & - & 2 & - & - & 1 & 1 & 1 & - & - & - & - & 5\end{array}$




\section{Pleuronectes microcephalus (Don.).}

Post-larvæ of this species, between 5 and $14 \mathrm{~mm}$ * in length and almost all between 6 and $11 \mathrm{~mm}$., were in the daytime on June 3rd mainly distributed from about 15 metres downwards (Fig. 5). At dusk there was evidence that they had slightly extended their distribution upwards to about 10 metres, and in the dark they were more or less evenly distributed from 10 metres downwards, but above this level they were almost absent, there being only 3 at the surface and one at $4 \cdot 6$ metres. At dawn the numbers were really too small to be significant, but the largest catch was made at 20.5 metres. In the daylight on June 4 th again the numbers were low and the largest catch occurred at $25 \cdot 7$ metres.

The evidence from this and the observations in preceding years, on which far fewer post-larvæ were caught, is that while in the daytime they live mostly below 15 metres, at night they tend to move about at all depths from about 10 metres downwards, but only a few reach actually to the surface or to 5 metres.

Only one post-larva of Pleuronectes flesus L. was caught, at $25 \cdot 3$ metres at dusk.

\section{SOLEID $A$.}

\section{Solea variegata (Don.).}

Post-larvæ of $S$. variegata, between 4 and $8 \mathrm{~mm}$. in length, were most abundant below 10 metres in the daytime on June 3rd (Fig. 6). At dusk they were slightly higher in the water, being most abundant at about 10 metres. In the dark they were almost evenly distributed from about 10 metres downwards, while a certain number had extended to the surface itself. At dawn the majority were below 10 metres, but the numbers caught were very small. In daylight on June 4th there were indications of a movement towards the surface again as with other species, the numbers were still, however, very low compared with the day before, evidently due to unevenness in horizontal distribution.

At dusk two metamorphosing post-larvæ, of 9 and $10 \mathrm{~mm}$., appeared at $19 \cdot 7$ and $30 \cdot 3$ metres respectively, while in the dark three were taken, one each at $4 \cdot 6,12 \cdot 3$, and $25 \cdot 9$ metres. Four early bottom stages also were caught in the dark, two at 25.9 metres and two at 35 metres.

Only two specimens of Solea vulgaris (Quenn.) were caught, one at 31.5 metres in daylight on June 3rd and one at $25 \cdot 3$ metres at dusk.

\footnotetext{
dusk.

* One metamorphosed specimen, $19 \mathrm{~mm}$. in length, was taken in the deepest haul at NEW Series.-Vol. Xv. No. 3. November, 1928. 


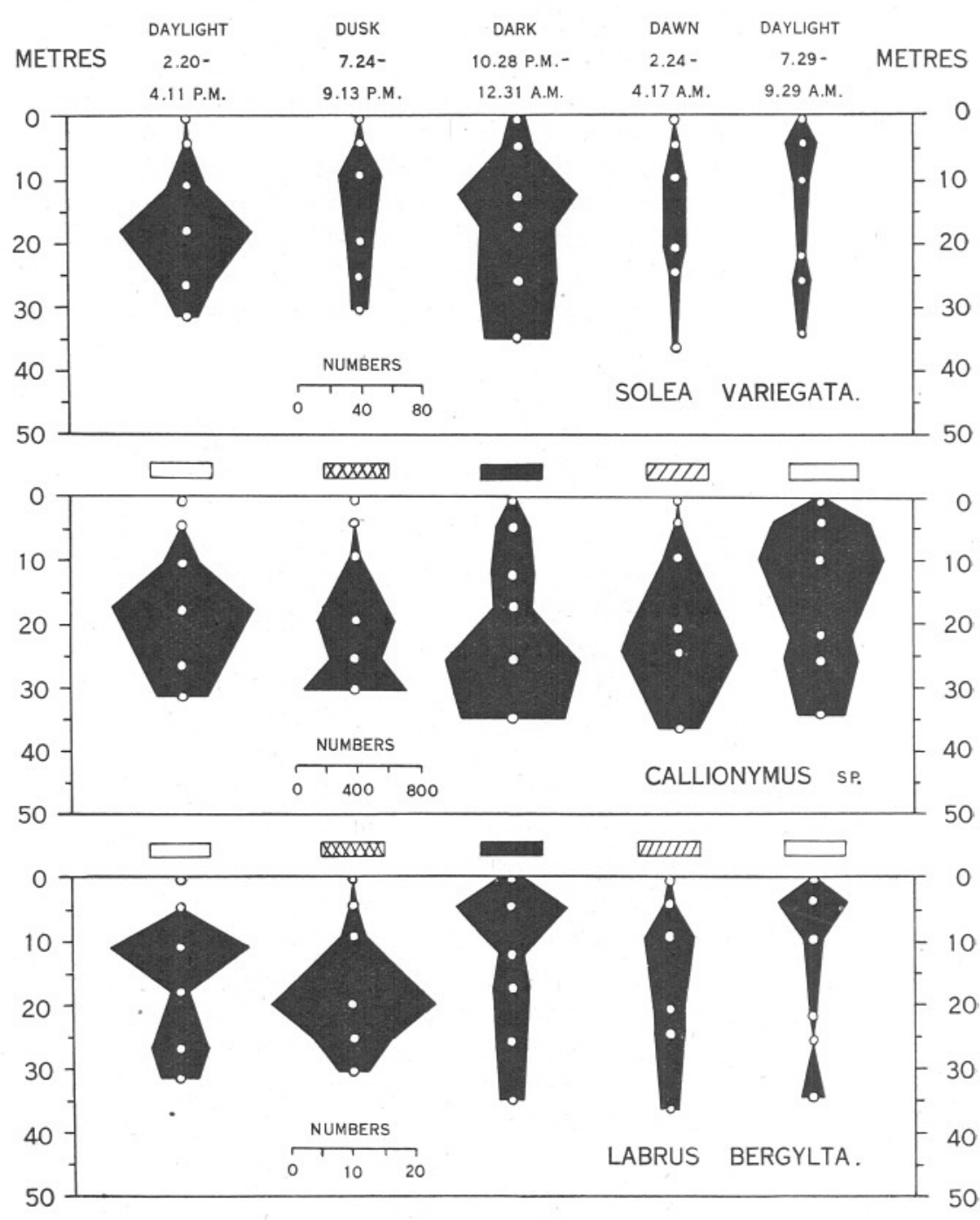

Fia. 6.-The vertical distribution of Solea variegata, Callionymus sp., and Labrus bergylta, at the times shown, on June 3rd-4th, 1926. The white spots and black circles indicate the "average depths " at which hauls were taken. The plain, cross-hatched, black, and shaded rectangles represent "daylight," "dusk," "dark," and "dawn" respectively. 


\section{AMMODYTID $A$.}

\section{Ammodytes lanceolatus (Lesauv.).}

Post-larvæ of $A$. lanceolatus, mostly about 6 to $25 \mathrm{~mm}$. in length, occurred rather unevenly distributed from the surface downwards in daylight on June 3rd. At dusk they were absent above about 10 metres, while in the dark they were again present from the surface downwards. At dawn there were none in the two upper hauls at the surface and at 4 metres, and in the daytime on June 4th only a few were taken, but none actually at the surface itself.

Only very few larvæ of $A$. tobianus were caught.

\section{CALLIONYMID $Æ$.}

Post-larvæ of Callionymus sp., probably almost all $C$. lyra, were as usual very abundant in the collections. In the daytime the majority lay below 10 metres (Fig. 6), and at dusk there had been little change in the distribution, but slightly fewer were caught. In the dark, although the majority were still below 15 metres, quite a large number had extended up to 5 metres and a few even to the surface itself. By dawn the surface layers had been vacated, and the majority lay again below 10 metres. In daylight on June 4th there had been a considerable upward movement, the same as that shown by the post-larvæ of $S$. norvegicus and commented on in the account of that fish.

As on the previous occasion a few late post-larval and early bottom stages appeared in the deeper layers in the dark.

\section{LABRID $Æ$.}

Of the post-larval wrasses those of Labrus bergylta, 4-7 mm. long, were the most numerous. In the daytime on June 3rd they avoided the actual surface layers and the majority were taken at 10.75 metres (Fig. 6). At dusk they had moved considerably deeper in the water and the largest catch was at $19 \cdot 7$ metres. In the dark there was an upward movement again, most being caught at 4.6 metres. At dawn they were evenly distributed from 4 metres downwards, although fewer were caught. In the daylight on June 4th they had moved once more towards the surface.

Of the other species Labrus mixtus were much less abundant, but showed much the same behaviour as $L$. bergylta. But the catches of Crenilabrus melops and Centrolabrus exoletus were too small to be significant. 


\section{SCOMBRID $A$.}

Only very few post-larvæ of Scomber scomber were taken.

\section{GOBIID $A$}

Fig. 2, page 834, shows that there was a marked increase of these postlarvæ at all depths in the dark except at the surface itself. In this respect the results repeat the behaviour shown on the two nights in June, 1925, but differ from that of July, 1924 (3, p. 411), when no indication of marked upward movement was shown and the young gobies were already well up in the water in the daytime.

Only very few post-larvæ of Lebetus scorpioides (Coll.) were taken, and then only in the deeper layers.

As is usually the case, a few Crystallogobius nilssoni appeared in the deeper hauls in the dark, these fish living actually on the bottom in the daytime.

\section{BLENNIID A.}

Post-larvæ of Blennius pholis (L.) and B. gattorugine (L.) both appeared in small numbers in the catches and their distribution was somewhat indiscriminate, with the usual tendency for a preference for the upper layers.

\section{TRIGLID $\nRightarrow$.}

\section{Trigla SP.}

Post-larval gurnards, mostly between 6 and $11 \mathrm{~mm}$. in length, were taken in the daylight on June 3rd chiefly below 10 metres. At dusk far fewer were caught, but they were still in the same layers. In the dark there had been a definite extension into the upper layers, even to the surface itself, but the numbers taken were rather small. At dawn the majority were again distributed at about 10 metres and lower, but in daylight on June 4th, although the numbers caught were extremely small, there was an indication that they had moved up higher in the water as did Scophthalmus and Callionymus.

\section{COTTID $Æ$.}

Cottus bubalis post-larvæ were extremely rare and then only occurred singly. 


\section{GOBIESOCID $A$.}

\section{Lepadogaster bimaculatus (Penn.).}

Although post-larvæ of this species were not very abundant they showed a marked tendency to move into the upper layers in the dark, being deep down in the daylight.

\section{LOPHIID A.}

\section{LOPHIUS PISCATORIUS (L.).}

Only three specimens of these post-larvæ occurred in the catches.

\section{SUMMARY.}

1. Results are given of a further series of collections made with the stramin ring-trawl to determine the diurnal behaviour of post-larval stages of Teleostean fishes in the Plymouth area.

2 . The catches were very satisfactory and showed that in no case, except for Clupeids and Gobies, was there any really marked movement of young fish towards the surface. This confirms previous observations.

3. It has been shown on this and previous occasions that Clupeids are many times more abundant in the catches at night than in the daytime, and any study of their seasonal or horizontal distribution would probably have to be carried out at night.

4. For the remaining species, except perhaps Gobies and Callionymus, oblique hauls taken either at day or at night should give a fair picture of seasonal or horizontal distribution. More observations are, however, required.

5. The association of the whiting young with the medusa, Cyanea capillata, is discussed.

\section{REFERENCES.}

1. Damas, D. Contribution à la biologie des Gadides. Conseil Perm. Internat. pour l'Explor. de la Mer. Rapp. et Proc. Verb., Vol. X. Special Part, No. 3. 1909.

2. Johansen, A. C. On the Diurnal Vertical Movements of Young of some Fishes in Danish Waters. Medd. fra Komm. for Havundersogelser. Serie Fiskeri., Bd. VIII, Nr. 2. 1925.

3. Russell, F. S. The Vertical Distribution of Marine Macroplankton. III. Diurnal Observations on the Pelagic Young of Teleostean Fishes in the Plymouth Area. Journ. Mar. Biol. Assoc.. N.S., Vol. XIV, No. 2, p. 387. 1926. 
TABLE X.-Young Fish Caught, June 3RD-4th, 1926.

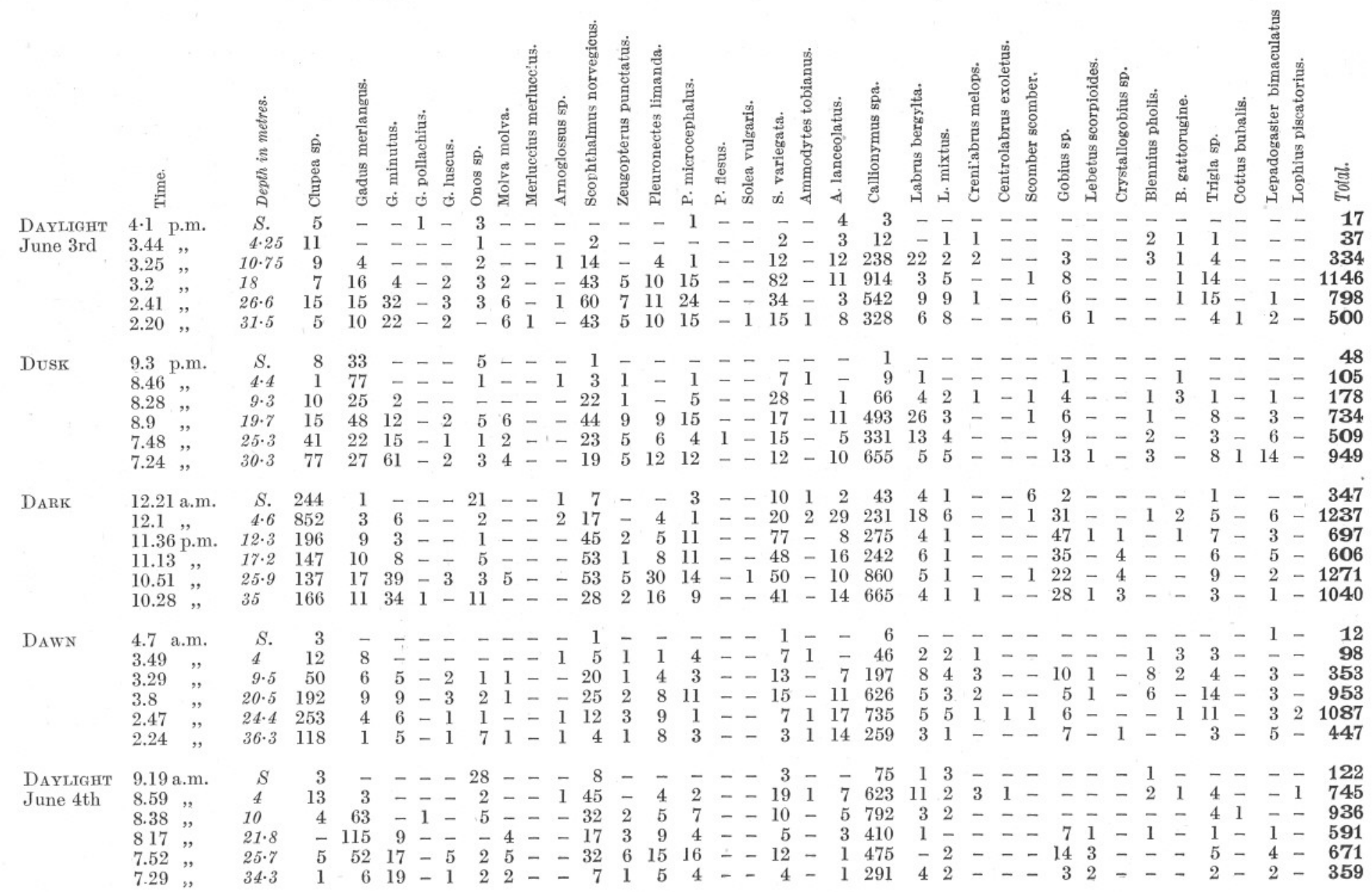

